\title{
Effect of Maturation on Phenolics and Flavonoids Content of Greenhouse-Grown Beet Leaf
}

\author{
Phunchok Angmo, Sonam Chorol, Desyong Namgail, OP Chaurasia, Tsering Stobdan*
}

\section{Phunchok Angmo, Sonam Chorol, Desyong Namgail, OP Chaurasia, Tsering Stobdan*}

Defence Institute of High Altitude Research, Defence $R \&$ D Organisation, LehLadakh-194101, INDIA.

\section{Correspondence \\ Tsering Stobdan}

Defence Institute of High Altitude Research, Defence R \& D Organisation, Leh-Ladakh-194101, INDIA.

Phone no: +91-9419176057

E-mail: ts_mbb@yahoo.com

History

- Submission Date: 18-06-2019;

- Review completed: 24-06-2019;

- Accepted Date: 01-07-2019.

DOI : 10.5530/pj.2019.11.159

Article Available online

http://www.phcogj.com/v11/i5

\section{Copyright}

(C) 2019 Phcogi.Com. This is an openaccess article distributed under the terms of the Creative Commons Attribution 4.0 International license.

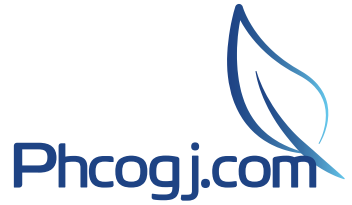

\begin{abstract}
Objective: This study aims to determine how maturation stages of greenhouse-grown beet leaf influence the total phenolic content (TPC) and total flavonoid content (TFC). Methods: Beet leaf was grown under two different passive solar greenhouses in trans-Himalayan Ladakh. Leaves harvested at three maturity stages were evaluated for TPC and TFC. Results: Significant difference in TPC and TFC was observed between the three maturity stages. Midmature leaves had the highest TPC and TFC followed by mature and immature leaves. When TPC and TFC for all maturity stages were averaged, a marked difference in TPC and TFC was observed in beet leaf grown under the two passive solar greenhouses. Higher TPC and TFC were observed in the greenhouse with higher photosynthetically active radiation (PAR) and UV-transmittance. Conclusion: Beet leaf should be harvested at the midmaturity stage for consumer to benefit from elevated levels of phenolics and flavonoids.

Key words: Antioxidants, Greenhouse, Ladakh, Vegetable, Maturity.
\end{abstract}

\section{INTRODUCTION}

Natural products for food and nutritional supplements have gained increased attention in recent years. In this context, there is an increasing interest in the beneficial health effects of plant derived compounds. Epidemiological and experimental studies reveal a negative correlation between the consumption of diets rich in fruits and vegetables and the risk of degenerative diseases including cancer, heart disease, inflammation, arthritis, immune system decline, brain dysfunction and cataracts. ${ }^{1-3}$ These physiological functions of fruits and vegetables may be partly attributed by their abundance of phenolics, including flavonoids. ${ }^{4}$ These results have stimulated research to characterize different types of plants with regards to their health promoting compounds.

The high mountain region of Ladakh is characterized by a rugged topography at an average altitude of over $3000 \mathrm{~m}$ asl. A considerable body of literature exists documenting that the production of free radical increases in human exposed to the environment associated with high altitude. Potential sources of stressors that might elicit the oxidative stress response at high altitude include exercise, ultraviolet radiation, catecholamines, anoxia/reoxygenation, hypoxanthine, xanthine oxidase and reductive stress. In addition to the natural constraints, nutritional needs play a vital role. $^{5}$

Meeting the requirement of fresh vegetables for people living in the remote mountain areas, especially during winter months is a formidable challenge. Growing vegetables is feasible only under greenhouse conditions during winter months due to sub-zero temperature. Passive solar greenhouse has played a significant role in Ladakh in production of leafy vegetables during winter months, ${ }^{6}$ and beet leaf is a popular leafy vegetable widely grown in greenhouses in Ladakh. The aim of this study was to determine how maturation stages of beet leaf grown under two passive solar greenhouses differing in photosynthetically active radiation (PAR) and UV-transmittance influences the total phenolic content (TPC) and total flavonoid content (TFC). We hypothesized that different maturity stages and microclimate would alter the health promoting compounds in beet leaf.

\section{MATERIALS AND METHODS}

\section{Study site and growing conditions}

Beet leaf was cultivated in two different passive solar greenhouses viz. Polyench and Polynet at the Defence Institute of High Altitude Research in transHimalayan Ladakh, India $\left(34^{\circ} 08.2^{\prime} \mathrm{N} ; 77^{\circ} 34.3^{\prime} \mathrm{E}\right.$, elevation $3340 \mathrm{~m}$ ). Polyench is a semi-underground passive solar greenhouse covered with UV stabilized 120 grams per square meter (GSM) translucent polyethylene sheet on wooden poles on south facing side. Polynet is a dual-purpose greenhouse in east-west orientation. It is used for drying fruits in summer and growing leafy vegetables in spring and winter. It is covered with a red shade netting (60\%) and UV stabilized 120 GSM translucent polyethylene sheet. ${ }^{7}$ No supplementary lighting and heating was provided. Temperature and relative humidity were recorded with hygro-thermometer (445702, Extech Instruments). The light intensity was recorded with light meter (HD450, Extech Instruments), and PAR was recorded with radiometer (PMA2100, Solar Light) with PAR detector (PMA2132). The weather and microclimate data of the two greenhouses are shown in Table 1.

Cite this article: Angmo P, Chorol S, Namgail D, Chaurasia OP, Stobdan T. Effect of Maturation on Phenolics and Flavonoids Content of Greenhouse-Grown Beet Leaf. Pharmacog J. 2019;11(5):1010-3. 


\section{Leaf sampling}

Seedlings were transplanted in the greenhouses in late October 2016 and leaves harvested in early March 2017 were used for analysis. The leaves were collected on the same day from 10 randomly selected plants at three maturity stages: immature (small leaves obtained from the top of the plant, leaf area $50.8 \pm 12.9 \mathrm{~cm}^{2}$ ), midmature (medium sized leaves obtained from the middle of the plant, leaf area $150.1 \pm 23.8 \mathrm{~cm}^{2}$ ), and mature (large leaves obtained from the base of the plant, leaf area 300.6 $\pm 60.6 \mathrm{~cm}^{2}$ ). Leaves were analyzed the same day after harvest. Total soluble solids (TSS) was measured with refractometer (ATAGO, Tokyo) and values were corrected at $20^{\circ} \mathrm{C}$.

\section{Preparation of samples}

Fresh leaves (leaf blade + petiole) were homoginised with the help of mortar and pistil and subjected to two cycles of extraction with methanol. Each sample $(200 \mathrm{mg})$ was extracted for $15 \mathrm{~min}$ with 1.5 $\mathrm{ml}$ of methanol in a $2 \mathrm{ml}$ micro centrifuge tube and vortexed at room temperature at $1100 \mathrm{rpm}$. The sample was then centrifuged at $5600 \mathrm{~g}$ for $10 \mathrm{~min}$ and the supernatant was recovered. The same procedure was repeated for the second cycle of extraction. The supernatant from both the extracts were combined to determine phenolics and flavonoids.

\section{Determination of total phenolic content}

The Folin-Ciocalteu reagent assay was used to determine the TPC. ${ }^{8}$ An aliquot of the samples was introduced into 96 well micro-plate followed by Folin-Ciocalteu reagent, which was previously diluted with distilled water (1:10), and sodium carbonate (7.5\%) was then added after $5 \mathrm{~min}$. The micro-plates were vortexed, covered with parafilm and allowed to stand for $30 \mathrm{~min}$. Absorbance at $765 \mathrm{~nm}$ was recorded in a micro-plate reader (SpectroMax M2 e, Molecular Devices, Sunnyvale, CA, United States). TPC was expressed in gallic acid equivalents (mg GAE/100 g FW).

\section{Determination of total flavonoids content}

Estimation of the TFC was carried out using the method of Zhishen et al. ${ }^{9}$ Briefly, to $0.5 \mathrm{ml}$ of sample, $0.15 \mathrm{ml}$ of $5 \% \mathrm{NaNO}_{2}$ was added. $10 \%$ $\mathrm{AlCl}_{3}(0.15 \mathrm{ml})$ was then added 5 min later. After $6 \mathrm{~min}, 1 \mathrm{M} \mathrm{NaOH}$ was added. Absorbance was measured at $415 \mathrm{~nm}$. TFC was expressed as quercetin equivalent $(\mathrm{QE})$. Final content was expressed as $\mathrm{mg} \mathrm{QE} / 100$ g FW.

\section{Statistical analysis}

All the experiments were performed in triplicate. The experimental results were expressed as mean \pm standard deviation (SD) using statistical analysis with SPSS (Statistical Program for Social Sciences, SPSS Corporation, Chicago, Illinois, USA). One way analysis of variance (ANOVA) and Independent Student t-test were done using SPSS 22.0 version for Windows.

\section{RESULTS AND DISCUSSION}

\section{Maturity effects in Polyench greenhouse}

Significant difference in TPC and TFC was observed between the three maturity stages (Table 2). Midmature leaves had the highest TPC $(104.7 \pm 5.3 \mathrm{mg} \mathrm{GAE} / 100 \mathrm{~g} \mathrm{FW})$ and TFC $(99.0 \pm 5.8 \mathrm{mg} \mathrm{QE} / 100$ g FW) followed by mature and immature leaves. TPC increased $13.9 \%$ from the immature to mature stage and then decreased $9.0 \%$ from the midmature to mature stage. Similarly, TFC increased $21.6 \%$ from the immature to mature stage and then decreased $17.5 \%$ from the midmature to mature stage. TSS was observed to be highest in midmature stage $\left(10.4 \pm 0.7^{\circ} \mathrm{Brix}\right)$ following by mature $(10.2 \pm$ $1.5^{\circ}$ Brix $)$ and immature stages $\left(8.7 \pm 0.8^{\circ}\right.$ Brix $)$. The results indicate that the synthesis of phenolics, including flavonoids, occurred readily from the immature to midmature stage and then may have slowed or ceased as leaves expanded to the mature stage. If the leaves accumulate solids during expansion and phenolic synthesis was arrested, then a reduction in phenolics would occur because of a dilution effect. Similar

Table 1: Temperature, humidity, light intensity, PAR and UV-B transmittance inside two passive solar greenhouses.

\begin{tabular}{|c|c|c|c|c|c|c|}
\hline \multirow[t]{3}{*}{ Parameters } & \multicolumn{3}{|c|}{ Polyench greenhouse } & \multicolumn{3}{|c|}{ Polynet greenhouse } \\
\hline & \multicolumn{3}{|c|}{ Month } & \multicolumn{3}{|c|}{ Month } \\
\hline & January & February & March & January & February & March \\
\hline Max temperature $\left({ }^{\circ} \mathrm{C}\right)$ & $24.6 \pm 3.1$ & $25.9 \pm 3.7$ & $36.0 \pm 5.1$ & $21.5 \pm 7.9$ & $27.9 \pm 9.7$ & $33.9 \pm 6.5$ \\
\hline Min temperature $\left({ }^{\circ} \mathrm{C}\right)$ & $-2.1 \pm 1.8$ & $1.6 \pm 2.3$ & $6.3 \pm 2.4$ & $-2.7 \pm 2.0$ & $0.5 \pm 2.5$ & $4.7 \pm 3.3$ \\
\hline Max relative humidity (\%) & $72.0 \pm 4.8$ & $82.5 \pm 4.1$ & $88.8 \pm 3.8$ & $93.5 \pm 1.0$ & $93.1 \pm 2.2$ & $91.0 \pm 5.6$ \\
\hline Min relative humidity (\%) & $38.4 \pm 8.8$ & $36.7 \pm 8.8$ & $37.1 \pm 9.6$ & $54.2 \pm 9.6$ & $50.2 \pm 11.4$ & $37.2 \pm 10.3$ \\
\hline Light intensity (Lux) at noon & $32310 \pm 13673$ & $46877 \pm 14045$ & $82413 \pm 31488$ & $8968 \pm 3795$ & $17664 \pm 5292$ & $26127 \pm 9983$ \\
\hline $\operatorname{PAR}\left(\mu \mathrm{mol} / \mathrm{m}^{2} \mathrm{~s}\right)$ at noon & $497.2 \pm 272.7$ & $837.2 \pm 274.9$ & $681.3 \pm 181.1$ & $167.1 \pm 91.6$ & $369.9 \pm 121.5$ & $357.9 \pm 95.1$ \\
\hline UV-B $\left(\mu \mathrm{W} / \mathrm{cm}^{2}\right)$ at noon & $1.74 \pm 0.73$ & $3.52 \pm 1.45$ & $4.37 \pm 1.14$ & $0.37 \pm 0.16$ & $0.84 \pm 0.35$ & $1.01 \pm 0.29$ \\
\hline
\end{tabular}

Values represented mean \pm SD

Table 2: Total phenolics, total flavonoids, total soluble solids (TSS) and petiole to leaf blade ratio of greenhouse-grown beet leaf at three maturity stages.

\begin{tabular}{|c|c|c|c|c|c|}
\hline Greenhouse & Maturity stage & $\begin{array}{c}\text { Total phenolics } \\
\text { (mg GAE/100g FW) }\end{array}$ & $\begin{array}{l}\text { Total flavonoids } \\
\text { (mg QE/100g FW) }\end{array}$ & $\begin{array}{c}\text { TSS } \\
\left({ }^{\circ} \text { Brix }\right) \\
\end{array}$ & Petiole: leaf blade \\
\hline \multirow{4}{*}{ Polyench } & Immature & $91.9 \pm 10.9^{\mathrm{a}}$ & $81.4 \pm 12.4^{\mathrm{a}}$ & $8.7 \pm 0.8^{\mathrm{a}}$ & $0.21 \pm 0.06^{\mathrm{a}}$ \\
\hline & Midmature & $104.7 \pm 5.3^{\mathrm{b}}$ & $99.0 \pm 5.8^{\mathrm{b}}$ & $10.4 \pm 0.7^{\mathrm{b}}$ & $0.53 \pm 0.11^{\mathrm{b}}$ \\
\hline & Mature & $95.3 \pm 8.0^{\mathrm{ab}}$ & $81.7 \pm 19.2^{\mathrm{a}}$ & $10.2 \pm 1.5^{\mathrm{b}}$ & $0.82 \pm 0.13^{c}$ \\
\hline & Average & $97.3 \pm 9.7^{* * *}$ & $87.4 \pm 10.0^{*}$ & $9.7 \pm 1.3^{* * *}$ & $0.52 \pm 0.28$ \\
\hline \multirow{4}{*}{ Polynet } & Immature & $74.1 \pm 12.4^{\mathrm{x}}$ & $73.3 \pm 9.9^{x}$ & $7.0 \pm 0.7^{x}$ & $0.38 \pm 0.16^{\mathrm{x}}$ \\
\hline & Midmature & $94.1 \pm 15.1^{y}$ & $93.3 \pm 20.9^{x}$ & $9.0 \pm 1.0^{y}$ & $0.55 \pm 0.29^{x y}$ \\
\hline & Mature & $77.5 \pm 18.2^{x y}$ & $78.1 \pm 26.7^{x}$ & $8.4 \pm 0.6^{y}$ & $0.89 \pm 0.32^{y}$ \\
\hline & Average & $81.9 \pm 17.3$ & $81.5 \pm 10.4$ & $8.2 \pm 1.1$ & $0.61 \pm 0.30^{*}$ \\
\hline
\end{tabular}

Values represented mean $\pm \mathrm{SD}$; for each column different uppercase letters within a greenhouse indicate significantly different at $p<0.05$; For all maturity stages the average value were significantly different between the two greenhouses by Independent Student t-test; " significant at $p \leq 0.05$; ${ }^{* *}$ Significant at $p \leq 0.01$; ${ }^{* *}$ Significant at $p \leq 0.001$. 
trend was observed in spinach leaves. ${ }^{10}$ Decrease in TPC and TFC from midmature to mature stage could also be because of increase in petiole to leaf blade ratio $(\mathrm{w} / \mathrm{w})$ at mature stage (Table 2). Petiole of spinach leaves is reported to have approximately 2.3 times lower phenolics than the leaf blade. ${ }^{11}$

\section{Maturity effects in Polynet greenhouse}

Maturity stages had marked effect on TPC and TFC in beet leaf (Table 2). Midmature leaves had the highest TPC $(94.1 \pm 15.1 \mathrm{mg} \mathrm{GAE} / 100 \mathrm{~g}$ $\mathrm{FW})$ and TFC $(93.3 \pm 20.9 \mathrm{mg} \mathrm{QE} / 100 \mathrm{~g} \mathrm{FW})$ followed by mature and immature leaves. TPC increased $27.0 \%$ from the immature to mature stage and then decreased $17.6 \%$ from the midmature to mature stage. Similarly, TFC increased $27.3 \%$ from the immature to mature stage and then decreased $16.3 \%$ from the midmature to mature stage.

\section{Microclimate effects on phenolics and flavonoids}

When TPC and TFC for all maturity stages were averaged, a marked difference in TPC and TFC was observed in beet leaf grown under the two passive solar greenhouses (Table 2). The mean TPC of beet leaf under Polyench $(97.3 \pm 9.7 \mathrm{mg} \mathrm{GAE} / 100 \mathrm{~g} \mathrm{FW})$ was significantly higher than that of Polynet $(81.9 \pm 17.3 \mathrm{mg}$ GAE/100 g FW $)$. Similarly, TFC was significantly higher in Polyench-grown beet leaf $(87.4 \pm 10.0 \mathrm{mg}$ $\mathrm{QE} / 100 \mathrm{~g} \mathrm{FW})$ as compared to that of Polynet-grown plants $(81.5 \pm$ $10.4 \mathrm{mg} \mathrm{QE} / 100 \mathrm{~g} \mathrm{FW})$. The two greenhouses differ in temperature, humidity, light intensity, PAR and UV-transmittance (Table 1). Higher TPC and TFC in Polyench-grown crop may be due to higher UV-transmittance as compared to that of Polynet greenhouse. UV radiation is regarded as a stress factor. Plant produces a wide range of flavonoids and related phenolic compounds in response to UV radiation. ${ }^{12,13}$ Generally, increasing UV-B radiation induces flavonoids and phenolics synthesis. ${ }^{14-16}$ Higher level of PAR inside Polyench may also be responsible for higher TPC and TFC in beet leaf. It has been demonstrated in bean leaves that high level of PAR gave a higher concentration of flavonoids than a low level of PAR. ${ }^{17}$ Decreased level of TFC in Polynet grown leaves due to shade netting is in agreement with reports on baby spinach. ${ }^{18}$

\section{CONCLUSION}

Beet leaf harvested at the midmature stage had much higher levels of total phenolics and total flavonoids than immature and mature leaves. Therefore, beet leaf should be harvested at the midmaturity stage for consumer to benefit from elevated levels of phenolics and flavonoids. When total phenolics and total flanonoids for all maturity stages were averaged, significantly higher phenolics and flavonoids were observed in the greenhouse with higher PAR and UV-transmittance.

\section{ACKNOWLEDGEMENT}

The study was supported by the Defence Research and Development Organisation (DRDO), Ministry of Defence, Government of India. PA and SC are grateful to DRDO for providing research fellowship.

\section{CONFLICTS OF INTEREST}

There is no conflict of interest.

\section{ABBREVIATIONS}

ANOVA: Analysis of variance; FW: Fresh weight; PAR: photosynthetically active radiation; SD: Standard deviation; SPSS: Statistical Program for Social Sciences; UV: Ultra violet radiation.

\section{REFERENCES}

1. Ames BN, Shigenaga MK, Hagen TM. Oxidants, antioxidants, and the degenerative diseases of aging. Proc Natl Acad Sci USA. 1993;90:7915-22.

2. Gordon $\mathrm{MH}$. Dietary antioxidants in disease prevention. Nat Prod Rep 1996;13(4):265-73

3. Halliwell B. Antioxidants in human health and disease. Ann Rev Nutr 1996; 16:33-50

4. Lin J-Y, Tang CY. Determination of total phenolic and flavonoid contents in selected fruits and vegetables, as well as their stimulatory effects on mouse splenocyte proliferation. Food Chem. 2007;101:140-7.

5. Askew EW. Work at high altitude and oxidative stress: antioxidant nutrients Toxicol. 2002;180:107-19.

6. Angmo S, Angmo P, Dolkar D, Norbu T, Paljor E, Kumar B, et al. All year round vegetable cultivation in trenches in cold arid trans-Himalayan Ladakh. Def Life Sci J. 2017;2(1):54-8

7. Angmo P, Dolma T, Namgail D, Tamchos T, Norbu T, Chaurasia OP, et al. Passive solar greenhouse for round the year vegetable cultivation in trans-Himalayan Ladakh region, India. Def Life Sci J. 2019;4(2):103-16.

8. Singleton VL, Rossi JA. Colorimetry of total phenolics with phosphomolybdicphosphotungstic acid reagents. Am J Enol Vitic. 1965;16:144-58.

9. Zhishen J, Mengcheng T, Jianming W. The determination of flavonoid contents in mulberry and their scavenging effects on superoxide radicals. Food Chem. 1999;64:555-9.

10. Pandjaitan N, Howard LR, MorelockT, Gil MI. Antioxidant capacity and phenolic content of spinach as affected by genetics and maturation. J Agric Food Chem. 2005;53:8618-23.

11. Machado RMA, Alves-Pereira I, Ferreira RMA. Plant growth, phytochemical accumulation and antioxidant activity of substrate-grown spinach. Heliyon. 2018;4 e00751.

12. Tevini M, Teramura AH. UVB effects on terrestrial plants. Photochem Photobiol. 1989;50:479-87.

13. Rozema J, Staaij J, Bjorn LO, Caldwell M. UV-B as an environmental factor in plant life: stress and regulation. Trends Ecol Evol. 1997;12:22-8.

14. Olsson LC, Veit M, Weissenböck G, Bornman JF. Differential flavonoid response to enhanced UV-B radiation in Brassica napus. Phytochem. 1998;49:1021-28.

15. Liu L, Gitz DCl, McClure JW. Effects of UV-B on flavonoids, ferulic acid, growth and photosynthesis in barley primary leaves. Physiol Plant. 1995;93:725-33.

16. Tsormpatsidis E, Henbest RGC, Davis FJ, Battey NH, Hadley P, Wagstaffe A UV irradiance as a major influence on growth, development and secondary products of commercial importance in Lollo Rosso lettuce 'Revolution' grown under polyethylene films. Environ Exp Bot. 2008;63:232-9.

17. Can YP, Bornman JF. The response of bean plants to UV-B radiation under different irradiances of background visible light. J Exp Bot. 1990;41:1489-95.

18. Bergquist SÅM, Gertsson UE, Nordmark LYG, Olsson ME. Effects of shade nettings, sowing time and storage on baby spinach flavonoids. J Sci Food Agr 2007;87:2464-71. 
GRAPHICAL ABSTRACT

Effect of leaf maturity on total phenolics and flavonoids content

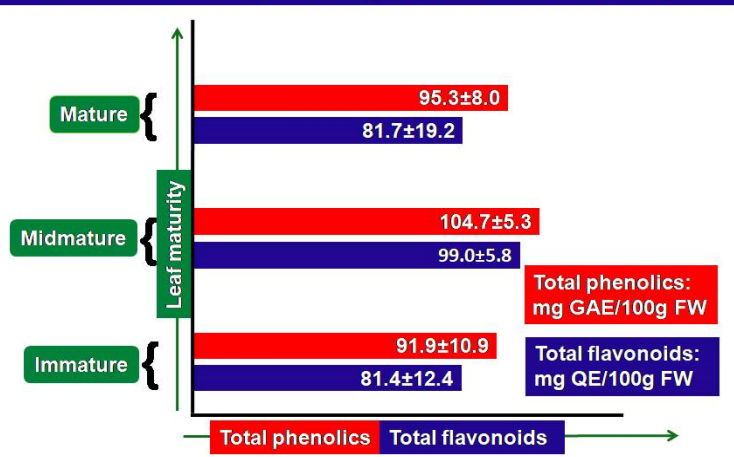

\section{SUMMARY}

- Beet leaf harvested at three maturity stages were evaluated for phenolics and flavonoid content.

- Midmature leaves had the highest phenolics and flavonoids followed by mature and immature leaves.

- Beet leaf should be harvested at the midmaturity stage to benefit from elevated levels of phenolics and flavonoids.

- Higher phenolics and flavonoids were observed in the greenhouse with higher PAR and UV-transmittance.

\section{ABOUT AUTHORS}

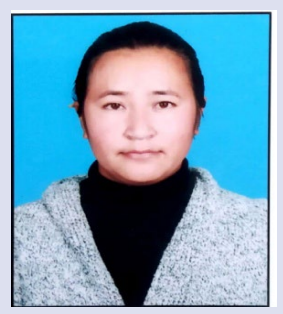

Ms Phunchok Angmo is Senior Research Fellow and Ph.D candidate in the Plant Science Division, DRDO-Defence Institute of High Altitude Research, Leh. She currently works on a project entitled 'Quality and yield of vegetables under different greenhouse structures in trans-Himalayan Ladakh, India'. She holds M.Sc in Botany from Panjab University.

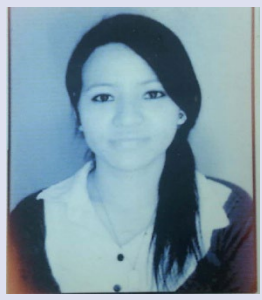

Ms Sonam Chorol, received her MSc (Botany) from Mysore University. Currently working as a Senior Research Fellow and pursuing her PhD in the Plant Science Division, DRDO-Defence Institute of High Altitude Research, Leh. She is currently workings on a project on biochemical profiling and storage of local radish (Raphanus sativis L.)

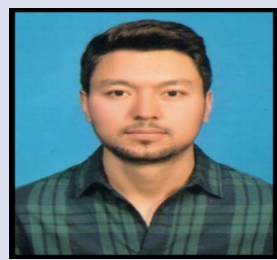

Sh Desyong Namgail received his BSc from Jammu University. Currently working as Senior Technical Assistant 'A' in Plant Science Division at DRDO-Defence Institute of High Altitude Research, Leh.

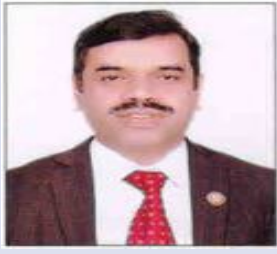

Dr. OP Chaurasia is Scientist ' $G$ ' and Director, Defence Institute of High Altitude Research. He obtained his Ph.D degree in Botany from Magadh University Bodh Gaya, Bihar in 1992. He specialised in trans-Himalayan medicinal plants.

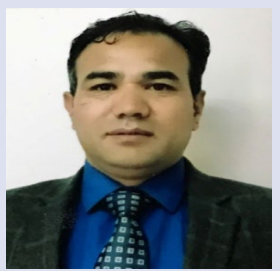

Dr. Tsering Stobdan is Scientist ' $E$ ' and Head, Plant Science Division at Defence Institute of High Altitude Research. He received his Ph.D in Molecular Biology \& Biotechnology from Indian Agricultural Research Institute, New Delhi.

Cite this article: Angmo P, Chorol S, Namgail D, Chaurasia OP, Stobdan T. Effect of Maturation on Phenolics and Flavonoids Content of Greenhouse-Grown Beet Leaf. Pharmacog J. 2019;11(5):1010-3. 